\title{
TRANSTIBIAL VERSUS ANTEROMEDIAL PORTAL TECHNIQUES IN ACL RECONSTRUCTION
}

\author{
TÉCNICA TRANSTIBIAL VERSUS TRANSPORTAL MEDIAL NA RECONSTRUÇÃO DO LCA
}

TÉCNICA TRANSTIBIAL VERSUS TRANSPORTAL EN RECONSTRUCCIÓN DEL LCA

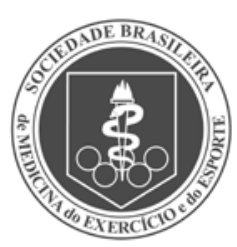

Artigo Original

Original Article

Artículo Original
Luiz Gabriel Betoni Guglielmetti ${ }^{1}$ (Médico)

Ricardo de Paula Leite Cury' (Médico)

Victor Marques de Oliveira' (Médico)

Osmar Pedro Arbix de Camargo' (Médico)

Fabrício Roberto Severino' (Médico) Nilson Roberto Severino' (Médico) Patrícia Maria de Moraes Barros Fucs' (Médica)

1. Department of Orthopaedic and Traumatology, Santa Casa Medical School and Hospitals, São Paulo, Brazil

\section{Correspondência:}

Rua Pascal 1292, Ap. 91,

Campo Belo, São Paulo, SP, Brazil. 04616-004

luizgbg@terra.com.br

\begin{abstract}
Introduction: Although the results of anterior cruciate ligament (ACL) reconstruction are well documented in many studies, with good to excellent outcomes in most cases, some issues like tunnel positioning are still discussed and studied. Objective: To compare the objective and subjective clinical outcomes of ACL reconstruction using the transtibial and anteromedial portal techniques. Methods: Prospective randomized study of 80 patients undergoing anterior cruciate ligament reconstruction by the same surgeon, with 40 patients operated by the transtibial technique and 40 by anteromedial portal technique. The patients, 34 in the transtibial group and 37 in the anteromedial portal group (nine dropouts), were reassessed during a 2-year follow-up period. The clinical assessment consisted of physical examination, KT-1000TM evaluation, Lysholm score, and objective and subjective International Knee Documentation Committee - IKDC scores. Results: Regarding the Lachman and pivot shift tests, we observed more cases of instability in the transtibial group, but with no statistical significance ( $p=0.300$ and $p=0.634$, respectively). Regarding the anterior drawer test, the groups presented similar results ( $p=0.977$ ). Regarding KT-1000TM evaluation, the mean results were 1.44 for the transtibial group and 1.23 for the anteromedial portal group, with no statistical significance $(p=0.548)$. We separated the objective IKDC scores into two groups: Group 1, IKDC A, and Group 2, IKDC B, C, or D, with no statistical significance $(p=0.208)$. Concerning the Lysholm score, the transtibial group had a mean score of 91.32, and the anteromedial portal group had a mean score of 92.81. The mean subjective IKDC scores were 90.65 for the transtibial group and 92.65 for the anteromedial portal group. Three re-ruptures were encountered in the transtibial group and three in the anteromedial portal group. Conclusions: There were no significant differences in the subjective and objective clinical assessments among patients submitted to anterior cruciate ligament reconstruction using the transtibial or anteromedial portal techniques.
\end{abstract}

Keywords: anterior cruciate ligament; knee; reconstruction.

\section{RESUMO}

Introdução: Embora a reconstrução do ligamento cruzado anterior (LCA) proporcione resultados clínicos bons e excelentes na maioria dos estudos, algumas questões ainda são discutidas e estudadas, como o posicionamento dos túneis. Objetivo: Comparar os resultados clínicos objetivos e subjetivos da reconstrução do LCA entre duas técnicas, a transtibial e a transportal medial. Métodos: Estudo prospectivo e randomizado de 80 pacientes submetidos à reconstrução do LCA pelo mesmo cirurgião, com 40 pacientes operados pela técnica transtibial e 40 pela técnica transportal medial. Ocorreram nove desistências, sendo 34 pacientes do grupo transtibial e 37 do grupo transportal medial, reavaliados durante dois anos de seguimento. A avaliação utilizou exame físico, avaliação com KT-1000TM, escores de Lysholm e (International Knee Documentation Committee) - IKDC (objetivo e subjetivo). Resultados: Nos testes de Lachman e pivot shift, foram observados mais casos de instabilidade no grupo transtibial, porém sem significância estatística ( $p=0,300$ e $p=0,634$, respectivamente). Em relação ao teste de "gaveta anterior", os resultados foram semelhantes $(p=0,977)$. A avaliação com KT-1000TM apresentou resultado médio de 1,44 no grupo transtibial e 1,23 no grupo transportal medial, sem diferença estatística $(p=0,548)$. Os resultados do IKDC objetivo foram separados em 2 grupos: Grupo 1, pacientes com IKDC A e grupo 2, pacientes com IKDC B, C ou D, sem diferença estatisticamente significante $(p=0,208)$. Em relação ao escore de Lysholm, o grupo transtibial teve uma pontuação média de 91,32 e 0 grupo transportal medial teve 92,81. O escore médio do IKDC subjetivo foi de 90,65 no grupo transtibial e de 92,65 no grupo transportal medial. Três rerrupturas foram encontradas no grupo transtibial e três no grupo transportal medial. Conclusões: Não foram encontradas diferenças com significância estatística nas avaliações objetivas e subjetivas, ao comparar pacientes submetidos à reconstrução do LCA pelas técnicas transtibial e transportal medial.

Descritores: ligamento cruzado anterior; joelho; reconstrução.

\section{RESUMEN}

Introducción: Aunque los resultados del ligamento cruzado anterior (LCA) están bien documentados en numerosos estudios, con buenos a excelentes resultados en la mayoría de los casos, algunos temas como el posicionamiento del túnel todavía son discutidos yestudiados. Objetivo: Comparar los resultados clínicos objetivos y subjetivos de la reconstrucción del LCA utilizando la técnica transtibial y la técnica transportal. Métodos: Estudio prospectivo aleatorizado de 80 pacientes sometidos a reconstrucción del ligamento cruzado anterior por el mismo cirujano, con 40 pacientes operados mediante 
la técnica transtibial y 40 mediante técnica transportal. Hubo nueve pérdidas y 34 pacientes del grupo transtibial y 37 en del grupo transportal fueron re-evaluados durante un período de seguimiento de 2 años. La evaluación clínica consistió en examen físico, evaluación KT-1000TM, puntuaciones de Lysholm e (International Knee Documentation Committee) - IKDC objetiva y subjetiva. Resultados: En cuanto a la prueba de Lachman y la prueba de pivot shift, hemos observado más casos de inestabilidad en el grupo transtibial, pero sin significación estadística ( $p=0,300$ y $p=0,634$, respectivamente). En cuanto a la prueba del cajón anterior, los grupos presentaron resultados similares ( $p=0,977)$. En cuanto a la evaluación con $K T$-1000TM, los resultados promedio fueron de 1,44 para el grupo transtibialy 1,23 para el grupo transportal, sin significación estadística $(p=0,548)$. Separamos las puntuaciones IKDC objetivo en dos grupos: Grupo 1, pacientes con IKDC Ay Grupo 2, pacientes con IKDC B, Co D, sin significación estadística ( $p=$ 0,208). En lo que respecta a la puntuación de Lysholm, el grupo transtibial tenía puntuación media de 91,32 y el grupo transportal tuvo puntuación media de 92,81. Las puntuaciones medias de IKDC subjetivo fueron 90,65 para el grupo transtibial y 92,65 para el grupo transportal. Tres re-roturas fueron encontradas en el grupo transtibial y tres en el grupo transportal. Conclusiones: No hubo diferencias significativas en las evaluaciones clínicas subjetivas y objetivas entre los pacientes sometidos a la reconstrucción del ligamento cruzado anterior utilizando las técnicas transtibial y transportal.

Descriptores: ligamento cruzado anterior; rodilla; reconstrucción.

\section{INTRODUCTION}

Anterior cruciate ligament $(A C L)$ reconstruction is one of the most commonly performed surgeries in Orthopedics. The results of this procedure are well documented in many studies, with good to excellent outcomes in most cases, but some issues regarding fixation methods ${ }^{1}$ and tunnel positioning are still discussed and studied².

Femoral tunnel positioning and drilling may be performed using a guide through the tibial tunnel (transtibial technique), or anatomically (from outside to inside or through the medial portal). The transtibial technique has been widely used in the last two decades ${ }^{3}$. However, anatomical studies have shown that tunnel positioning using this technique, the tibial tunnel dictates the femoral tunnel, and the result is a graft not centered at the ACL origin $^{2,4}$. Biomechanical ${ }^{2,5}$ and clinical ${ }^{6,7}$ studies have shown advantages regarding the stability acquired with a more anatomical positioning of the femoral tunnel compared with the transtibial technique, but there is not a consensus regarding long term clinical results and rerupture ${ }^{8}$.

The objective of this study is to compare the objective and subjective clinical outcomes of transtibial versus anteromedial portal techniques in anterior cruciate ligament reconstruction using autologous flexor tendon grafts. The primary hypothesis is that the anteromedial portal technique would provide better objective outcomes. We also hypothesized that anteromedial portal ACL reconstruction would result in better subjective findings.

\section{METHODS}

From August 2010 to May 2012, 145 patients (knees) underwent surgical ACL reconstruction at our institution (Santa Casa de São Paulo, Brazil). Of these cases, 80 met the study's inclusion criteria: unilateral ACL injury; patients with mature skeletons and closed physes; age below 40 years; knees with no previous surgery on the injured side (except arthroscopic meniscectomy); no degenerative changes on arthroscopy; time of injury less than one year and greater than two weeks; absence of associated ligament injuries (except grades I and II medial collateral ligaments); and absence of morbid obesity (Figure 1).

The patients were operated on by the same surgeon or under his supervision or assistance. The patients were prospectively selected and randomly allocated to two groups: the transtibial group (TT) and the anteromedial portal group (AM). The study was approved by the Institution's Ethics Committee (number 291/10), and all patients signed consent forms.

Randomization was performed by simple draw, with folded pieces of paper containing the name of the technique (transtibial or anteromedial) that were placed inside an opaque envelope. Eighty envelopes, forty transtibial and forty anteromedial, were placed in a box. Once the inclusion criteria were met, a patient was drawn. After an envelope was drawn, it was not returned to the box. The sample size (eighty knees)

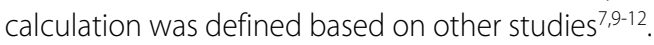

Eighty patients, 59 males and 21 females, underwent surgery. There were 43 right knees and 37 left knees. The mean patient age was 24 years old (15 to 40 years). The mean time to surgery was 6.5 months ( 2 weeks to 1 year). Of the 80 patients, 74 practiced some physical activity before the injury. The preoperative subjective IKDC score and mean Lysholm score were 66.74 (37 to 90) and 69.25 (38 to 96), respectively. The patients were allocated into two groups according to the surgical technique: the TT group and the AM group. In the TT group, 65\% of the patients were male and 35\% were female. In the AM group, $82.5 \%$ were male and $17.5 \%$ were female. The mean ages were 24.33 years for the TT group and 23.63 years for the AM group. The mean times of injury at the time of surgery were 6.7 months in the TT group and 6.2 months in the AM group. The age, gender, side (right or left), preoperative subjective IKDC and Lysholm scores, preoperative objective IKDC score and time of injury at the time of surgery did not differ significantly between the groups

The patients were preoperatively assessed using a KT1000 ${ }^{\mathrm{TM}}$ arthrometer (MEDmetric, San Diego, California) at 20 degrees of flexion and 133 N. The patients were also assessed using the Lachman, anterior drawer and pivot shift tests, the objective International Knee Documentation Committee $(\text { IKDC })^{13}$ score, the subjective IKDC score and the Lysholm scale ${ }^{14}$. The same surgeon in charge of the surgeries, applying the same preoperative criteria, performed the clinical examinations at those time points.

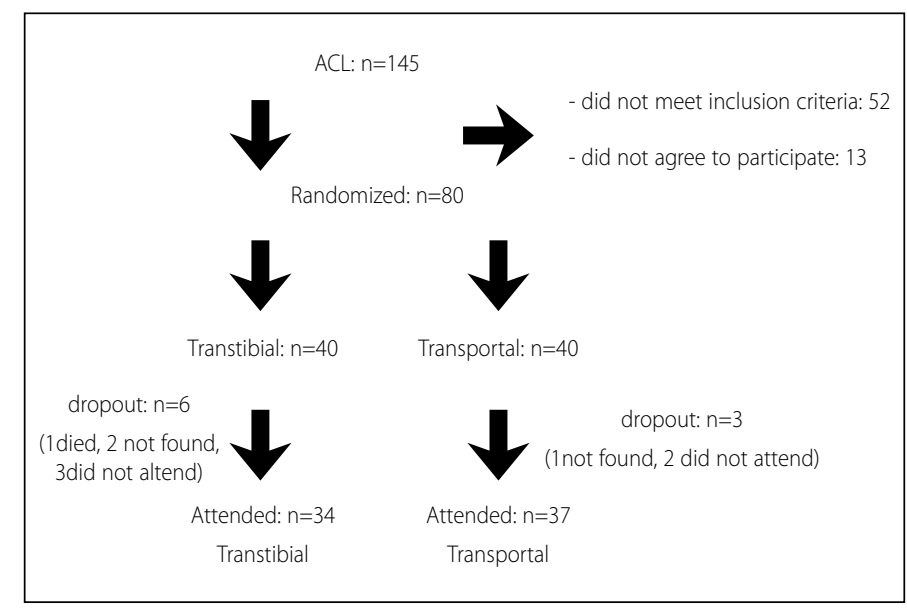

Figure1. Consort flow diagram. 
The surgical technique involved arthroscopy, treatment of eventual meniscal and chondral injuries, and $A C L$ reconstruction with fixation of the flexor tendon graft (semitendinosus and gracilis) on the tibia with a metal interference screw. In the femur, an Endo Tunnel Device (ETD; ${ }^{\circ}$ Prolnd, Cotia, São Paulo, Brazil), a suspension femoral fixation system ${ }^{15}$, was used (Figures 2-4).

The tibial tunnel was drilled with the knee in extension, using the guide in extension ( $65^{\circ}$ Howell Guide ${ }^{\circ}$; Biomet Sports Medicine Inc., Warsaw, IN). For the femoral tunnel, $\Pi T$ group, a conventional transtibial femoral guide (aimer) was placed on the posterior edge of the intercondyle. Before passing the guide wire (Kirschner 2.4), the guide was turned distally to reach a more horizontal position. For the AM group, the anterolateral portal was performed laterally to the patellar tendon, and the anteromedial portal was performed inferior and between the medial femoral condyle and patellar tendon to allow femoral tunnel drilling with no cartilage injury of the medial femoral condyle. With the knee at 90 degrees of flexion and the arthroscope on the lateral portal, an ice pick was introduced, and the center of the native $\mathrm{ACL}$ (anatomical positioning) was marked. Next, the positioning was checked with the arthroscope through the anteromedial portal. The guide wire (Kirschner 2.4) was introduced and positioned on the previously marked point, the knee was flexed between 120 and 130

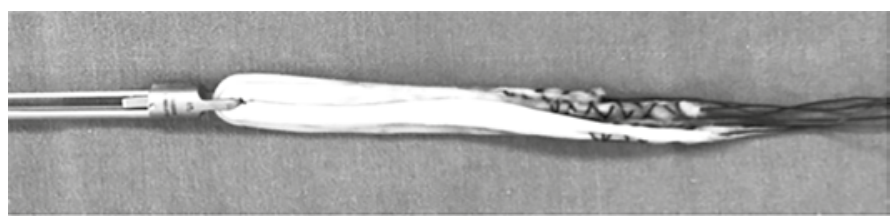

Figure 2. ETD ${ }^{\circledR}$ with the prepared graft (semitendinosus and gracilis tendons).

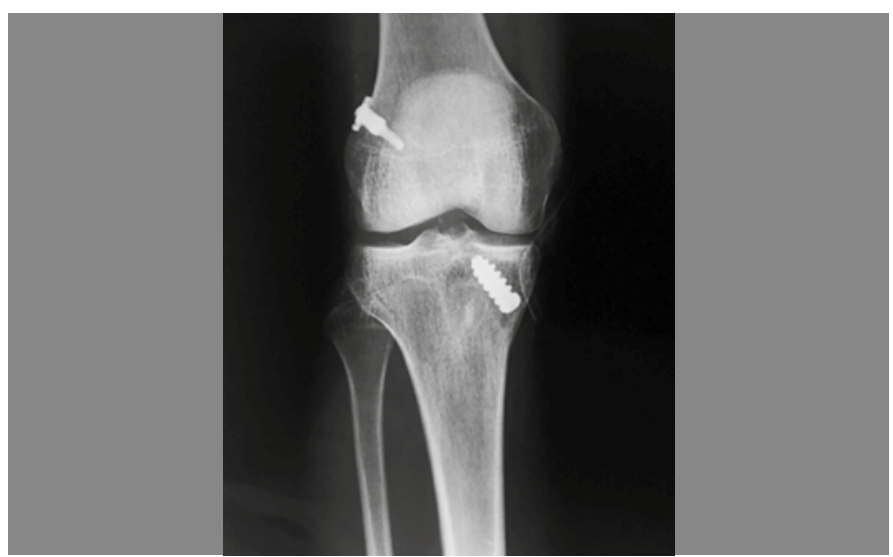

Figure 3. Postoperative anteroposterior radiograph of a right knee subjected to $A C L$ reconstruction showing femoral fixation with the ETD ${ }^{\circledR}$.

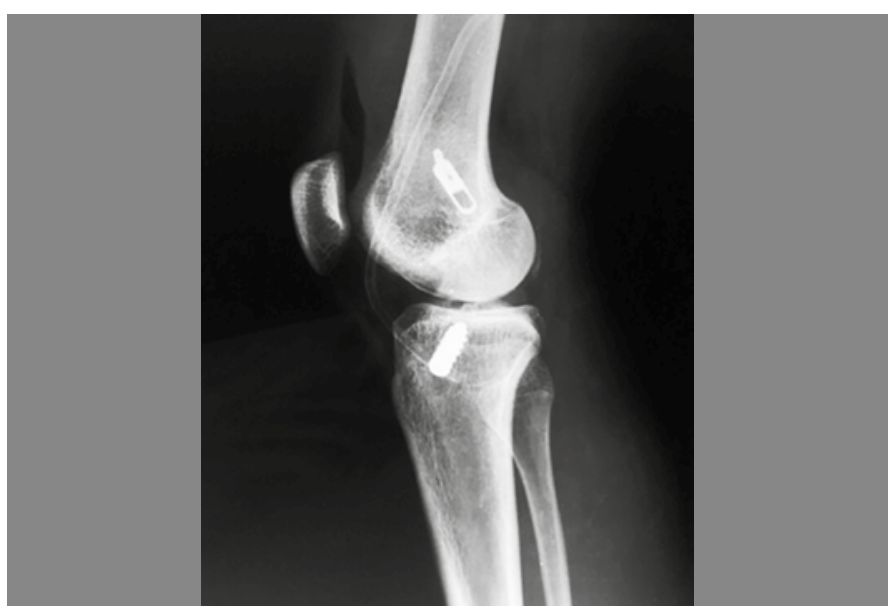

Figure 4. Lateral radiograph of the same case as in Figure 3. degrees, and the guide wire was then passed until it crossed the femoral lateral cortical area. The femoral tunnel was subsequently drilled with the respective drill bit. Figure 5 shows an example of both ACL positions, marked from transtibial and transortal techniques.

Both groups received the same institutional rehabilitation protocol.

The data collected were statistically analyzed using SPSS 13.0 for Windows (SPSS Inc). For the descriptive analysis, the qualitative variables were described using frequencies (numbers and percentages) and graphs. The quantitative variables were described using summary measures (means, medians, standard deviations, minima and maxima). For the qualitative vs. qualitative inferences, the chi-square test or Fisher's exact test was used. For the qualitative vs. quantitative inferences, Student's $t$ test (parametric) or Mann-Whitney test (non-parametric) was used, at a $5 \%$ significance level. Objective IKDC was chosen as the primary outcome. Power analysis, with a power of $80 \%$ and an a of .05, showed that a sample size of 16 patients in each group was needed for a 1 grade difference with a 1 grade SD in objective IKDC measurements.

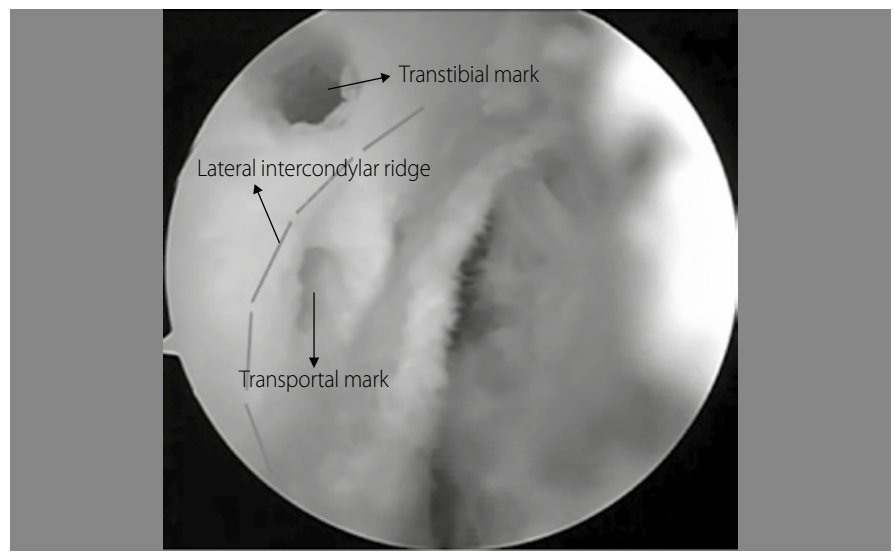

Figure 5. Example of both $A C L$ positions, marked from transtibial and transortal techniques.

\section{RESULTS}

Of the 80 patients, nine were not reassessed and were considered dropouts for three reasons: death (one patient), incorrect data for further contact (three patients) and not attending the reassessment (five patients). Therefore, 71 patients were assessed with 2 years of follow-up. Of these patients, 37 were operated upon using the anteromedial portal technique and 34 using the transtibial technique. The aforementioned preoperative data were assessed (age, gender, side [right or left], preoperative subjective IKDC and Lysholm scores, preoperative objective IKDC score and time of injury at the time of surgery). Excluding the nine dropouts, there were no significant differences in these data between the groups, indicating that the groups were homogeneous at the preoperative period.

The objective assessment 2 years after surgery consisted of a physical examination, arthrometry using a $\mathrm{KT} 1000^{\mathrm{TM}}$ arthrometer, and objective IKDC score (IKDCo) evaluation. Table 1 shows the results of the Lachman, pivot shift and anterior drawer tests at two years after surgery. Due to the numbers of qualitative variables in those tests $(0+, 1+, 2+$ and $3+)$, it was decided to divide the patients into normal $(0+) \mathrm{X}$ abnormal $(1+, 2+$ or $3+$ ) physical examinations and to compare them in relation to the transtibial or anteromedial portal technique to allow for statistical analysis. Regarding the Lachman and pivot shift tests, Table 1 indicates more cases of instability in the TT group, though with no statistical significance (chi-square test, $p=0.300$ and $p=0.634$, respectively). Regarding the anterior drawer test, the groups had similar results, also with no statistical significance ( $p=0.977$, chi-square test). 
Regarding the KT $1000^{\mathrm{TM}}$, the mean results were 1.44 for the TT group and 1.23 for the AM group, with no significant difference ( $p=0.548$, Student $t$ test). When separating the KT1000 ${ }^{\mathrm{TM}}$ results into two groups, up to $3 \mathrm{~mm}$ and greater than $3 \mathrm{~mm}$, and comparing the TT and AM groups (Table 2), similar results were observed ( $p=1$, Fisher's exact test).

The IKDCo scores for the $T$ T and AM techniques are presented in Table 3 with no differences between groups ( $p=0.220$, Mann-Whitney's test). We also separated the IKDCo scores in two groups. Group 1: patients with IKDCo A and Group 2: patients with IKDCo B, C or D. Table 4 shows this evaluation. Despite the apparently superior results of the AM group, there was no significant difference ( $p=0.208$, chi-square test).

The subjective assessment was performed using the Lysholm questionnaire and the subjective IKDC score. Table 5 shows this evaluation. The mean Lysholm scores were 91.32 for the TT group and 92.81 for the AM group, with no significant difference ( $p=0.701$, Mann-Whitney test). The mean subjective IKDC scores were 90.65 for the TT group and 92.65 for the AM group, also with no significant difference ( $p=0.639$, Mann-Whitney test).

Regarding intraoperative complications, in six cases (7.5\%), the ETD ${ }^{\circ}$ was fixated on soft tissue upon immediate postoperative radiographic assessment. Of these six cases, five were from the AM group and one from the TT group. The statistical analysis of the occurrence of this complication using either technique yielded a $p$ value of 0.201 (Fisher's exact test), i.e., no significant difference, as only a few cases presented the complication. There was one case of superficial infection (1.2\%) in the AM group, which was successfully treated only with antibiotics.

Regarding reruptures, patients that reported a traumatic torsion event followed by clinical instability were defined as rerupture cases. There were six reruptures, 3 in the TT group and 3 in the AM group, with no significant difference.

We also assessed the correlation between fixation of the ETD ${ }^{\circ}$ on soft tissues, the physical examination parameters (Lachman, pivot

Table 1. Lachman, Pivot shift and anterior drawer tests results of patients in the $T T$ and AM groups, 2 years after surgery.

\begin{tabular}{c|c|c|c|cc}
\hline \multirow{2}{*}{ Technique } & \multicolumn{5}{|c}{ Lachman } \\
\cline { 2 - 6 } & $\mathbf{0}$ & + & ++ & +++ & $\mathbf{p}$ \\
\hline TT & 24 & 7 & 3 & 0 & \\
\hline AM & 30 & 4 & 2 & 1 & \\
\hline Total & 54 & 11 & 5 & 1 & 0,300 \\
\hline
\end{tabular}

\begin{tabular}{c|c|c|c|c|c}
\hline \multirow{2}{*}{ Technique } & \multicolumn{5}{|c}{ Pivot shift } \\
\cline { 2 - 6 } & $\mathbf{0}$ & $\boldsymbol{+}$ & $\boldsymbol{+ +}$ & $\boldsymbol{+ + +}$ & $\mathbf{p}$ \\
\hline TT & 26 & 5 & 3 & 0 & \\
\hline AM & 30 & 4 & 3 & 0 & \\
\hline Total & 56 & 9 & 6 & 0 & 0,634 \\
\hline
\end{tabular}

\begin{tabular}{c|c|c|c|c|c}
\hline \multirow{2}{*}{ Technique } & \multicolumn{6}{|c}{ Anterior drawer } \\
\cline { 2 - 6 } & $\mathbf{0}$ & $\boldsymbol{+}$ & $\boldsymbol{+ +}$ & $\boldsymbol{+ + +}$ & $\mathbf{p}$ \\
\hline $\mathrm{TT}$ & 24 & 8 & 2 & 0 & \\
\hline $\mathrm{AM}$ & 26 & 9 & 2 & 0 & \\
\hline Total & 50 & 17 & 4 & 0 & 0,977 \\
\hline
\end{tabular}

TT: transtibial; AM: anteromedial portal. Source: SAME/ISCMSP and personal archive.

Table 2. KT1000TM exam results 2 years after surgery, showing the difference in the contralateral knee between the TT and AM groups.

\begin{tabular}{c|c|c|c}
\hline \multirow{2}{*}{ Technique } & \multicolumn{3}{|c}{ KT1000 $\mathbf{T M}^{\mathrm{T}}$ difference between knees } \\
\cline { 2 - 4 } & Up to $\mathbf{3} \mathbf{~ m m}$ & Greater than $\mathbf{3} \mathbf{~ m m}$ & $\mathbf{p}$ \\
\hline$T$ & 28 & 6 & \\
\hline AM & 31 & 6 & 1 \\
\hline Total & 59 & 12 & \\
\hline
\end{tabular}

shift and anterior drawer test), and the KT1000 ${ }^{\mathrm{TM}}$ and IKDCo scores at two years after surgery. When comparing the patients presenting ETD fixations on soft tissues with those not presenting that outcome using the aforementioned parameters, we observed similar results and, therefore, no significant difference between groups.

\section{DISCUSSION}

Some recent anatomical studies ${ }^{2,4}$ have shown that is not possible to reach the $A C L$ center using the transtibial technique. To reach the center using the transtibial technique, an extremely horizontal tibial tunnel is necessary, with risk of the tunnel being short and subchondral ${ }^{16}$. In the present study, more horizontal femoral tunnels were obtained because of the lateral rotation of the transtibial femoral guide. Some recent studies have used the modified transtibial technique with varus and internal rotation of the tibia when the transtibial guide is positioned on the femur, reaching a point very similar to the $\mathrm{ACL}$ center ${ }^{17}$. Some studies have reported similar outcomes between transtibial and anteromedial portal techniques ${ }^{9,10}$. Despite these studies, most studies comparing the transtibial technique with anatomical techniques (anteromedial portal or"outside-in") reported superior outcomes (objective and subjective) with the anatomical techniques ${ }^{2,5-7,11}$. A precise technical guidelines for the transtibial and anteromedial portal techniques was published ${ }^{18}$, stating that it is possible to drill similar tunnels using both techniques as long as the anatomical parameters and guide angles are respected; however, the advantage of the transtibial technique is not requiring knee hyperflexion, which hinders the surgical procedure. In turn, the dependence of the tibial tunnel orientation to drill the femoral tunnel is a difficulty factor for the transtibial technique because once the tibial tunnel is drilled, it cannot be changed ${ }^{4}$. However, we believe that when using the tibial guide in extension (Howell ${ }^{\mathrm{TM}} 65^{\circ}$ Tibial Guide - Biomet Sports Medicine Inc., Warsaw, Indiana), it is possible to drill a tibial tunnel with proper positioning and reproducibility because the knee anatomy and the guide's positioning angle are respected, compared with guides in flexion that depend exclusively on the surgeon's positioning.

Table 3. Objective IKDC scores ( $a, b, c, d)$ at 2 years after surgery for the TT and AM groups.

\begin{tabular}{c|c|c|c|c|c}
\hline \multirow{2}{*}{ Technique } & \multicolumn{7}{|c}{ IKDCo } \\
\cline { 2 - 6 } & $\mathbf{a}$ & $\mathbf{b}$ & $\mathbf{c}$ & $\mathbf{d}$ & $\mathbf{p}$ \\
\hline$T \mathrm{~T}$ & 20 & 11 & 3 & 0 & \\
\hline AM & 27 & 8 & 1 & 1 & \\
\hline Total & 47 & 19 & 4 & 1 & 0,220 \\
\hline
\end{tabular}

TT: transtibial; AM: anreomedial portal; IKDCo: objective International Knee Documentation Committee score. Source: SAME/ISCMSP and personal archive.

Table 4. Objective IKDC scores at 2 years after surgery for the TT and AM groups, with the objective IKDC scores separated into two groups (a vs. b, c or d).

\begin{tabular}{|c|c|c|c|}
\hline \multirow{2}{*}{ Technique } & \multicolumn{3}{|c|}{ IKDCo } \\
\hline & $a$ & b, c or d & $p$ \\
\hline TT & 20 & 14 & \\
\hline AM & 27 & 10 & \\
\hline Total & 47 & 24 & 0,208 \\
\hline
\end{tabular}

TT: transtibial; AM: anteromedial portal; IKDCo: objective International Knee Documentation Committee score. Source: SAME/ISCMSP and personal archive.

Table 5. Subjective IKDC scores and Lysholm scores at 2 years after surgery for the TT and AM groups.

\begin{tabular}{c|c|c}
\hline \multirow{2}{*}{ Technique } & IKDCs & Lysholm \\
\cline { 2 - 3 } & (mean) & (mean) \\
\hline TT & 90.65 & 91.32 \\
\hline AM & 92.65 & 92.81 \\
\hline $\mathrm{p}$ & 0.639 & 0.701 \\
\hline
\end{tabular}

TT: transtibial; AM: anteromedial portal; IKDCs: subjective International Knee Documentation Committee score Source: SAME/ISCMSP and personal archive. 
A systematic review published in $2015^{8}$ on the advantages and disadvantages of the transtibial, medial transportal and "outside-in" approaches found that despite the differences among these techniques, there is no gold standard for drilling the femoral tunnel.

The objective and subjective clinical results of the present study were similar between the TT and AM groups, with outcomes such as Lachman and pivot shift test results and an objective IKDC score that were slightly higher in the TP group but with no statistical significance. The small study size should be emphasized. Although many studies have similar case series, 6,12,19-21 because it is expected that the difference of the objective and subjective outcomes is slight, large samples are necessary to detect a significant difference. Therefore, the results presented in the tables in this study should be assessed carefully because we might have type II statistical errors (i.e., not detecting a difference although it exists). With a larger sample, such tests might indicate the superiority of one technique over the other. Some series comparing transtibial and anatomical techniques ${ }^{6,7}$ found better outcomes in patients submitted to the anatomical technique; however, those studies did not confirm the anatomical positioning of the femoral tunnel with postoperative imaging exams, as in the present study. In addition, there is still discussion about the ideal point to drill the tunnel, given that recent anatomical and histological studies ${ }^{22}$ have shown direct and indirect fibers on the $A C L$; thus, perhaps the ideal drill point is still undefined.

A question raised recently is if the anteromedial portal technique leads to more reruptures than the transtibial technique, given that a 2013 study that used cases in the Danish Knee Ligament Reconstruction Register ${ }^{23}$ reported more rerupture cases with the anteromedial portal technique. However, because that study was retrospective and assessed cases from several centers and surgeons and, as mentioned in the article, the surgeries were conducted at a time when the anteromedial portal technique was being popularized in Denmark, bad positioning of the femoral tunnel using the anteromedial portal technique may have occurred. A prospective cohort study published in 2013 reported the opposite findings, with more chance of rerupture in the transtibial cases compared with the transportal ${ }^{24}$ cases, and another series reported more cases of rerupture using the transtibial technique, but with no statistical significance ${ }^{25}$. In the present study, there were three cases of rerupture in each group.
Regarding surgical complications, ETD fixation on soft tissues occurred in six of 80 cases. Of these six cases, five were in the AM group and one was in the TT group. When comparing the patients with device fixation on soft tissues with those with no fixation on soft tissues, there were no objective and subjective clinical differences, corroborating the findings of a published clinical study ${ }^{26}$ assessing whether fixation of the endobutton on soft tissues or its migration would lead to worse clinical outcomes compared with patients without this complication. A total of $25.2 \%$ of the cases assessed had soft tissue interposition but with no clinical implications. Despite the lack of clinical implications, the authors recommend using immediate postoperative radiographs and, if such a complication is identified, correcting it. In that particular study, a double-bundle reconstruction was performed, and soft tissue interposition was more frequent in the posterolateral bundles. The authors suggest that this interposition occurs because of the lateral condyle anatomy, with ligament insertions and the close proximity of the iliotibial tract. Our study also found more cases of interposition in the ETDs ${ }^{\bullet}$ fixated more distally and laterally on the femur, which were the anteromedial portal cases; this result is in agreement with the explanation of the aforementioned study where the cause was the lateral condyle anatomy.

Some limitations of this study should be noted. All patients were operated on by the same surgeon, who also conducted all assessments (objective and subjective). The surgeon was not blinded; thus, the surgeon knew which technique had been applied to every patient. Another important factor is the sample size. As discussed before, future studies with larger samples and longer follow-up periods are needed. Another limitation is the fact that imaging exams were not conducted to confirm the femoral tunnel positioning in both techniques.

\section{CONCLUSION}

There were no significant differences in the objective clinical assessments between patients submitted to transtibial or anteromedial portal anterior cruciate ligament reconstruction. There was also no difference in subjective evaluations.

All authors have declared there is not any potential conflct of interests concerning this article.

AUTHORS' CONTRIBUTIONS: Each author contributed individually and significantly to the development of the manuscript. LGBG (0000-0003-2711-529X) * and NRS (0000-0002-1730-0216) * were the main contributors in the drafting of the manuscript. LGBG performed the surgery. FRS (0000-0002-6834-8615) * and VMO $(0000-0001-7236-4936) *$ followed patients and gathered clinical data. LGBG and PMMBF (0000-0001-7081-987X)* evaluated the data of the statistical analysis. LGBG, NRS, OPAC (0000-0001-7161-6046)* and RPLC (0000-0003-0507-4976) * carried out the literature search, review of the manuscript and contributed to the concept intellectual study. All authors reviewed the manuscript after completion. ${ }^{*} \mathrm{ORCID}$ (Open Researcher and Contributor ID).

\section{REFERENCES}

1. Milano G, Mulas PD, Ziranu F, Piras S, Manunta A, Fabbriciani C. Comparison between different femoral fixation devices for $\mathrm{ACL}$ reconstruction with doubled hamstring tendon graft: $\mathrm{A}$ biomechanical analysis. Arthroscopy. 2006;22(6):660-8.

2. Steiner ME, Battaglia TC, Heming JF, Rang JD, Festa A, Baria M. Independent drilling outperforms conventional transtibial drilling in anterior cruciate ligament reconstruction. Am J Sports Med. 2009;37(10):1912-9.

3. Steiner M. Anatomic single-bundle ACL reconstruction. Sports Med Arthrosc. 2009;17(4):247-51.

4. Heming JF, Rand J, Steiner ME. Anatomic limitations of transtibial drilling in anterior cruciate ligament reconstruction. Am J Sports Med. 2007;35(10):1708-15.

5. Bedi A, Musahl V, Steuber V, Kendoff D, Choi D, Allen AA, et al. Transtibial versus anteromedial portal reaming in anterior cruciate ligament reconstruction: An anatomic and biomechanical evaluation of surgical technique. Arthroscopy. 2011;27(3):380-90.

6. Alentorn-Geli E, Samitier G, Alvarez P, Steinbacher G, Cugat R. Anteromedial portal versus transtibial drilling techniques in $\mathrm{ACL}$ reconstruction: a blinded cross-sectional study at two-to five-year follow-up. Int Orthop. 2010(5);34:747-54

7. Hussein M, van Eck CF, Cretnik A, Dinevski D, Fu FH. Prospective randomized clinical evaluation of conventional single-bundle, anatomic single-bundle, and anatomic double-bundle anterior cruciate ligament reconstruction: 281 cases with 3- to 5-year follow-up. Am J Sports Med. 2012;40(3):512-20.
8. Robin BN, Jani SS, Marvil SC, Reid JB, Schillhammer CK, Lubowitz JH. Advantages and disadvantages of transtibial, anteromedial portal, and outside-in femoral tunnel drilling in single-bundle anterior cruciate ligament reconstruction: a systematic review. Arthroscopy. 2015;31(7):1412-7.

9. Sohn OJ, Lee DC, Park KH, Ahn HS. Comparison of the modified transtibial technique, anteromedia portal technique and outside-in technique in ACL reconstruction. Knee Surg Relat Res. 2014;26(4):241-8

10. Yourn YS, Cho SD, Lee SH, Youn CH. Modified transtibial versus anteromedial portal technique in anatomic single-bundle anterior cruciate ligament reconstruction: comparison of femoral tunnel position and clinical results. Am J Sports Med. 2014;42(12):2941-7.

11. Sim JA, Gadikota HR, Li JS, Li G, Gill TJ. Biomechanical evaluation of knee joint laxities and graft forces after anterior cruciate ligament reconstruction by anteromedial portal, outside-in, and transtibial techinques. Am J Sports Med. 2011;39(12):2604-10.

12. Hussein M, van Eck CF, Cretnik A, Dinevski D, Fu FH. Individualized anterior cruciate ligament surgery: a prospective study comparing anatomic single- and double-bundle reconstruction. Am J Sport Med. 2012;40(8):1781-8.

13. Anderson AF, Irrgang JJ, Kocher MS, Mann BJ, Harrast JJ. The international knee documentation committee subjective knee evaluation form: normative data. Am J Sports Med. 2006;34(1):128-35.

14. Lysholm J, Gillquist J. Evaluation of knee ligament surgery results with special emphasis on use of a scoring scale. Am J Sports Med. 1982;10(3):150-4. 
15. Guglielmetti LGB, Cury RPL, Oliveira VM, Camargo OPA, Severino NR, Fucs PMMB. Anterior cruciate ligament reconstruction: a new cortical suspension device for femoral fixation with transtibial and transportal techniques. J Orthop Surg Res. 2014;9:1-6.

16. Steiner ME. Surgical management of anterior cruciate ligament injuries. In: McKeon BP, Bono JV, Richmond JC, eds. Knee arthroscopy. New York: Springer-Verlag; 2008. p.129-52.

17. Lee JK, Lee S, Seong SC, Lee MC. Anatomic single-bundle ACL reconstruction is possible with use of the modified transtibial technique. J Bone Joint Surg Am. 2014:96(8):664-72.

18. Howell SM, Hull ML. Checkpoints for judging tunnel and anterior cruciate ligament graft placement J Knee Surg. 2009;22(2):161-70

19. Lee S, Kim H, Jang J, Seong SC, Lee MC. Comparison of anterior and rotatory laxity using navigation between single- and double-bundle $\mathrm{ACL}$ reconstruction: prospective randomized trial. Knee Surg Sports Traumatol Arthrosc. 2012;20(4):752-61

20. Kim MK, Lee BC, Park JH. Anatomic single bundle anterior cruciate ligament reconstruction by the two anteromedial portal method: the comparison of transportal and transtibial techniques. Knee Surg Relat Res. 2011;23(4):213-9.

21. Jepsen CF, Lundberg-Jensen AK, Faunoe P. Does the position of the femoral tunnel affect the laxity or clinical outcome of the anterior cruciate ligament-reconstructed knee? A clinical, prospective, randomized, double-blind study. Arthroscopy. 2007;23(12):1326-33.

22. Pathare NP, Nicholas SJ, Colbrunn R, McHugh MP. Kinematic analysis of the indirect femoral insertion of the anterior cruciate ligament: implications for anatomic femoral tunnel placement. Arthroscopy. 2014:30(11):1430-8

23. Rahr-Wagner $L$, Thillemann TM, Pedersen AB, Lind MC. Increased risk of revision after anteromedial compared with transtibial drilling of the femoral tunnel during primary anterior cruciate ligament reconstruction: results from the danish knee ligament reconstruction register. Arthroscopy. 2013;29(1):98-105

24. Duffee A, Magnussen RA, Pedroza AD, Flanigan DC, MOON Group, Kaeding CC. Transtibial ACL femoral tunnel preparation increases odds of repeat ipsilateral knee surgery. J Bone Joint Surg Am 2013;95(22):2035-42.

25. Franceschi F, Papalia R, Rizzello G, Buono AD, Maffulli N, Denaro V. Anteromedial portal versus transtibial drilling techniques in anterior cruciate ligament reconstruction: any clinical relevance? A retrospective comparative study. Arthroscopy. 2013;29(8):1330-7.

26. Mae T, Kuroda S, Matsumoto N. Migration of EndoButton after anatomic double-bundle anterio cruciate ligament reconstruction. Arthroscopy. 2011:27(11):1528-35. 